\title{
Bennett Timeline
}

1902 O Bennett born in Giddings, Texas (July 8).

ca. 1906 O Following her parents' divorce, Bennett is kidnapped by her father, Joshua, from her mother, Mayme. Bennett and her father remain on the run for several years. Bennett has no interaction with her mother for more than fifteen years.

1906-7 $\bigcirc$ Bennett and her father live in Washington, DC.

1914 O Joshua Bennett marries Marechal Neil (June 3).

1918-21 ○ Bennett attends Brooklyn Girl's High School.

1921 O Bennett graduates from Brooklyn Girl's High School (January).

1921-22 O Bennett studies at the Fine Arts Department of Teachers College, Columbia University.

1923 O Bennett's first magazine cover, "Christmas Carols," is published in Crisis (December).

“Heritage" (poetry) published in Opportunity (December).

1923-24 Bennett transfers to the Pratt Institute and completes her studies in art and drama.

1924 O New York Civic Club function (March 21). Bennett reads "To Usward" (poetry), which is later published simultaneously in Crisis and Opportunity.

Bennett becomes a faculty member of fine arts at Howard University, Washington, DC (Fall). She teaches design, watercolor, and crafts.

Bennett is awarded a $\$ 1,000$ scholarship from Delta Sigma Theta Sorority for continued study of art abroad (December).

Bennett takes leave from Howard and travels to Paris to begin her scholarship (June).

1926 O Bennett returns to the United States (Summer).

Bennett's father dies (August).

Bennett returns to Howard (Fall). 
Bennett becomes the assistant to the editor at Opportunity and starts publishing "The Ebony Flute" (column).

Bennett is on the editorial board of Fire!! along with Wallace Thurman, Langston Hughes, Zora Neale Hurston, Aaron Douglas, John P. Davis, and Richard Bruce Nugent.

Controversy surrounds Bennett's engagement to a Howard University student (Alfred Jackson); she resigns from Howard and works at a batik factory.

Bennett and Aaron Douglas invited to study with Dr. Albert C. Barnes at the Barnes Foundation in Marion, Pennsylvania.

Jackson completes his internship at Freedman's Hospital, moves to Eustis, Florida, and starts his own practice.

Bennett marries Dr. Alfred J. Jackson (April 14).

"The Ebony Flute" concludes (May).

Bennett teaches art at Tennessee State College over the summer and then moves to Eustis, Florida.

Bennett teaches art and Spanish at Curtright High School in Eustis, Florida.

Bennett visits New York and participates in library program

(December).

Bennett creates painting Untitled [River Landscape]. To date it is the only Bennett painting in existence.

Bennett travels to New York.

Bennett and Jackson move from Florida to Long Island, New York, where her husband starts his practice.

Bennett begins work at the W. C. Handy Music Publishing Company.

Bennett works at the Hempstead YMCA.

1934

Bennett starts working as a journalist for the Department of Information and Education of the Welfare Council of New York. Jackson's health continues to deteriorate.

Bennett maintains a separate residence from Jackson in a boarding house in Harlem. Norman Lewis also has a room at the same boarding house. The following year, Bennett begins a three-year relationship with Lewis. 
1935-41

1938

o Bennett is suspended as the director of the Harlem Community Arts Center (June 30).

1941-42 O Bennett teaches at the School for Democracy.

1943 O George Washington Carver School opens. Bennett is a founding member and serves as its director.

1947 O George Washington Carver School closes.

1948 O Bennett is hired by Consumers Union.

1968 O Bennett resigns from Consumers Union.

1970 O Bennett and Crosscup move to Kutztown, Pennsylvania, and open an antique store, Buttonwood Hollow Antiques.

1980 o Dick Crosscup dies (January 9).

1981 O Bennett dies in Reading, Pennsylvania (May 31). 